\title{
Numerical Analysis of Rapid Drawdown of an Embankment Dam
}

\author{
Amjad Hussain Bhutto \\ Department of Civil Engineering \\ Quaid-e-Awam University of \\ Engineering Science and Technology \\ Nawabshah, Pakistan \\ amjadbhutto62@gmail.com
}

\author{
Muhammad Auchar Zardari \\ Department of Civil Engineering \\ Quaid-e-Awam University of \\ Engineering, Science \& Technology \\ Nawabshah, Pakistan \\ muhammad.auchar@quest.edu.pk
}

\author{
Ghulam Shabir Bhurgri \\ Department of Civil Engineering \\ Quaid-e-Awam University of \\ Engineering Science and Technology \\ Nawabshah, Pakistan \\ ghulamshabirbhurgri14@gmail.com \\ Riaz Bhanbhro \\ Department of Civil Engineering \\ Quaid-e-Awam University of \\ Engineering Science and Technology \\ Nawabshah, Pakistan \\ riaz@quest.edu.pk
}

\author{
Shahnawaz Zardari \\ Department of Civil Engineering \\ Quaid-e-Awam University of \\ Engineering, Science \& Technology \\ Nawabshah, Pakistan \\ shahnawazzardari@gmail.com \\ Bashir Ahmed Memon \\ Department of Civil Engineering \\ Quaid-e-Awam University of \\ Engineering Science and Technology \\ Nawabshah, Pakistan \\ bashir_m@hotmail.com
}

\begin{abstract}
Numerical analysis for the safe rate determination of lowering of an embankment dam was performed in this study with the use of the finite element method. Coupled deformation and consolidation analysis were carried out for staged construction and drawdown of a $59 \mathrm{~m}$ embankment dam for varying undrained shear strength of the clay core. The lowering of the reservoir was performed at different depths between two extreme scenarios, i.e. rapid lowering rate $(1 \mathrm{~m} / \mathrm{day})$ and slow lowering rate $(0.1 \mathrm{~m} / \mathrm{day})$. The reservoir of the dam was lowered to a depth from $10 \mathrm{~m}$ to $55 \mathrm{~m}$ in gradual increments. The results indicated that the safety of the dam was satisfactory when the reservoir was lowered at the quick rate for a depth of $10 \mathrm{~m}, 20 \mathrm{~m}$, $30 \mathrm{~m}$ respectively when the undrained shear strength of the clay core was taken as 20,25 and $30 \mathrm{kN} / \mathrm{m}^{2}$. Regarding the case of slow drawdown rate of the reservoir, it was found that the reservoir could be lowered up to a depth of $55 \mathrm{~m}$ at a rate of $0.1 \mathrm{~m} /$ day when the undrained strength of clay core was $25 \mathrm{kN} / \mathrm{m}^{2}$. The stability of the dam was also found satisfactory even though the reservoir was lowered at a rate of $0.25 \mathrm{~m} / \mathrm{day}$ for a depth of $55 \mathrm{~m}$ when the undrained shear strength of clay core was $30 \mathrm{kN} / \mathrm{m}^{2}$.
\end{abstract}

Keywords-rapid drawdown; stability; safety factor; consolidation; undrained shear strength

\section{INTRODUCTION}

In this paper, slow and rapid drawdown of a rainfed embankment dam is presented. The reservoir of the dam lies in an area where the rainfall is erratic. This study focuses on the way the dam would behave if there was a rainfall shortage in the reservoir area and water would continue to be used. It is possible high rain intensity periods to give way to long drought periods. In this situation, it is very imperative to examine the safe rate of drawdown that could be allowed to discharge water. In addition, quick lowering of the reservoir could be necessary in a case of an emergency. The main parameters on which the safety of a dam depends are soil properties, pressure of water, and geometry [1-3]. In case of drawdown, pore pressures in the upstream side of the dam reduce which ultimately disturbs the equilibrium conditions of the dam. As a result, the upstream side of the dam is likely to slide due to imbalance of the water pressure that is present before lowering of the reservoir. When the reservoir level is increased, two types of pore pressure develop in the dam: seepage pore pressure and excess pore pressure. In an emergency, if it is required to lower the reservoir level, then the upstream face of the dam is likely to slide due to the presence of pore pressures, which have not dissipated as quickly as the lowering of the reservoir. This occurs because with the decrease of the water level there is a loss of stabilizing effect of water without decrease in pore pressure. If the permeability of the soil is low, it will take a long time to drain. Consequently, there might be a chance of sliding of the upstream slope of the dam. It has been found that the likelihood of failure of a dam depends on lowering speed, permeability, and the compressibility of the soil of the dam [4]. Rapid drawdown may occur, if the reservoir is lowered so rapidly that the soil does not have enough time to drain sufficiently.

The stability of embankment dams is very important for public safety and the economic development of a country. Stability of an embankment dam under rapid drawdown situation is complicated because of the time dependent generation of pore pressures in embankment and foundations. Such analysis may require advanced numerical tools based on finite element method [5]. Several embankment dam failures due to continuous lowering of the reservoir are reported in [510]. It is reported that the common rates of lowering of the reservoir range from $0.1 \mathrm{~m} /$ day to $1 \mathrm{~m} /$ day [11]. If the upstream face of the dam is of high permeability or the side slopes are 
flat, the embankment dams can sustain more drawdown as compared to the soils with low permeability. Since every embankment dam has specific geometry and foundation soils, the safe rate of lowering of the reservoir is site specific and varies, depending on the case.

\section{MATERIALS AND METHODS}

A rainfed dam located in Sindh province is analyzed with consideration of rapid drawdown conditions that might arise due to uneven distribution of rainfall and continuous discharge of water. The cross section of the dam is presented in Figure 1. The main material zones are sandy gravel, random fill, clay core, and sandy siltstone. In addition, grouting was provided to control seepage in the foundation. The numerical analysis was carried out with the finite element program Plaxis 2D [12]. The various soil material properties were obtained from field and laboratory tests [13] (Table I). For the development of the finite element model of the dam, the layers were gradually placed at a rate of three meters in thirty days. The ground water level is $15 \mathrm{~m}$ below the surface. After gradual raising of the dam at the specified rate, the reservoir was slowly filled in 120 days up to a level of $56.6 \mathrm{~m}$ (Figure 2). The stress strain behavior of all materials was modeled with Mohr-Coulomb Model. The gradual raising process of the dam was carried out with consolidation analysis. For computation of safety at various stages during the service life of the dam, safety analysis was performed.

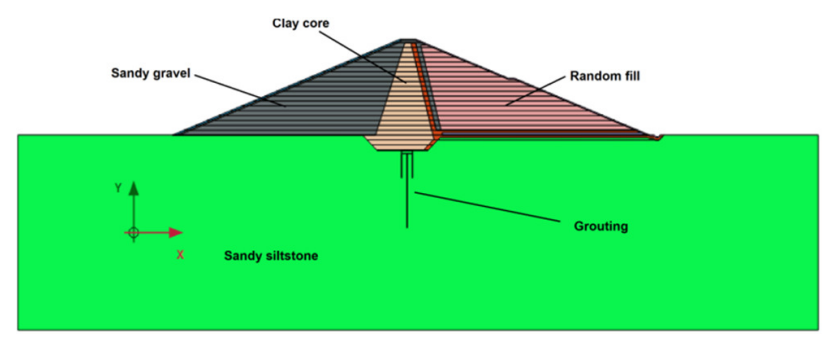

Fig. 1. Cross section of a rainfed embankment dam

TABLE I. MATERIAL PROPERTIES USED

\begin{tabular}{|c|c|c|c|c|c|}
\hline Material & $\begin{array}{c}\text { Saturated } \\
\text { unit } \\
\text { weight } \\
\left(\mathrm{kN} / \mathrm{m}^{3}\right) \\
\end{array}$ & $\begin{array}{c}\text { Cohesion } \\
\left(\mathrm{kN} / \mathrm{m}^{2}\right)\end{array}$ & $\begin{array}{c}\text { Friction } \\
\text { angle } \\
\text { (deg) }\end{array}$ & $\begin{array}{c}\text { Modulus of } \\
\text { elasticity } \\
\left(\mathbf{k N} / \mathbf{m}^{2}\right)\end{array}$ & $\begin{array}{c}\text { Permeability } \\
\text { (m/day) }\end{array}$ \\
\hline Clay & $18.85^{[13]}$ & $9.57^{[13]}$ & $30^{[13]}$ & $50000^{[13]}$ & $0.000263^{[13]}$ \\
\hline $\begin{array}{l}\text { Sandy } \\
\text { gravel }\end{array}$ & $21.5^{[14]}$ & 0 & $37^{[15-17]}$ & $50000^{[18]}$ & $86.4^{[19]}$ \\
\hline $\begin{array}{c}\text { Random } \\
\text { fill }\end{array}$ & $18.85^{[13]}$ & 0 & $34^{[13]}$ & $50000^{[13]}$ & $0.263^{[13]}$ \\
\hline $\begin{array}{c}\text { Washed } \\
\text { gravel }\end{array}$ & $21.5^{[14]}$ & 0 & $37^{[15-17]}$ & $45000^{[20]}$ & $864^{[21]}$ \\
\hline $\begin{array}{c}\text { D/s slope } \\
\text { protection }\end{array}$ & $19.5^{[22]}$ & 0 & $34^{[15-17]}$ & $40000^{[23-24]}$ & $8640^{[21]}$ \\
\hline Riprap & $19.5^{[13]}$ & 0 & $34^{[13]}$ & $40000^{[23-24]}$ & $8640^{[21]}$ \\
\hline $\begin{array}{l}\text { Sand } \\
\text { filter }\end{array}$ & $18.85^{[13]}$ & 0 & $36^{[13]}$ & $40220^{[13]}$ & $26.33^{[13]}$ \\
\hline $\begin{array}{c}\text { Drainage } \\
\text { blanket }\end{array}$ & $21.5^{[17]}$ & 0 & $37^{[15-17]}$ & $45000^{[21]}$ & $864^{[24]}$ \\
\hline $\begin{array}{c}\text { Sandy } \\
\text { siltstone }\end{array}$ & $20.4^{[13]}$ & $12^{[13]}$ & $29^{[13]}$ & $\begin{array}{c}70000 \text { to } \\
125000^{[25]}\end{array}$ & $0.00063^{[13]}$ \\
\hline
\end{tabular}

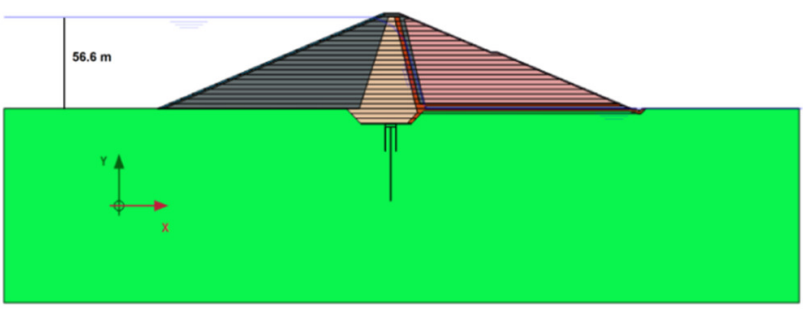

Fig. 2. High reservoir level location of the embankment dam

Rapid drawdown was carried out using coupled deformation and consolidation analysis. Before performing rapid drawdown calculations, the effective strength and stiffness parameters (see Table I) of the clay core were changed with undrained shear strength values of the clay core ranging between 20 to $30 \mathrm{kN} / \mathrm{m}^{2}$. The values of undrained shear strength were evaluated based on the consistency index [26]. The values were computed as:

$$
\begin{gathered}
\text { Consistency Index }=1-L I \\
L I=\frac{w-P L}{L L-P L}
\end{gathered}
$$

where $L I$ is the Liquidity Index, $w$ is the natural moisture content, $P L$ is the Plastic Limit, and $L L$ is the Liquid Limit of clay:

$$
L I=\frac{17.85-16.85}{20.5-16.85}=0.273
$$

Consistency Index $=1-L I=1-0.273=0.726$

Based on the Consistency Index value of 0.726, the undrained shear strength $(\mathrm{Su})$ of soil lies in the range of 20 to $40 \mathrm{kN} / \mathrm{m}^{2}$. In this paper, the drawdown calculations were performed for undrained strength of clay of 20,25 and $30 \mathrm{kN} / \mathrm{m}^{2}$. In addition, since the clay became saturated, its modulus of elasticity was taken as $30000 \mathrm{kN} / \mathrm{m}^{2}$ instead of the initial value of $50000 \mathrm{kN} / \mathrm{m}^{2}$. Drawdown of the dam was performed for different rates ranging from $1 \mathrm{~m} /$ day to $0.1 \mathrm{~m} /$ day. The lowest value of the drawdown was $10 \mathrm{~m}$ and highest was $55 \mathrm{~m}$ as shown in Figures 3 and 4 respectively.

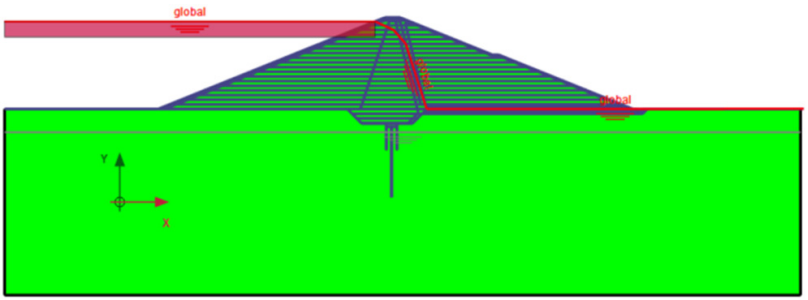

Fig. 3. $10 \mathrm{~m}$ lowering of the reservoir at the rate of $1 \mathrm{~m} /$ day

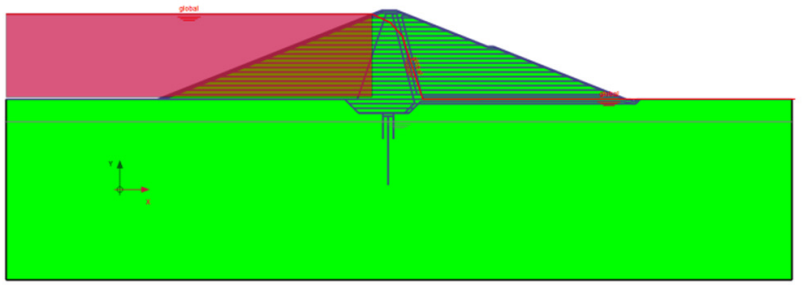

Fig. 4. A view of lowering of reservoir up to a depth of $55 \mathrm{~m}$ at $0.1 \mathrm{~m} /$ day 


\section{RESULTS AND DISCUSSION}

\section{A. Dam Stability at the End of Construction and After Filling} of the Reservoir

The stability of the dam was evaluated by computing the safety factor of the dam. The computed values of safety factor were 1.6 and 1.5 for the end of construction and after the filling of the reservoir respectively. The corresponding failure zones for the end of construction and after the filling of the reservoir conditions are shown in Figures 5 and 6. It can be observed that failure zone was developed on the upstream face at the end of construction, when regarding after the filling of the reservoir, failure zone was developed on the downstream side. This occurred because the reservoir water produced a stabilizing effect on the upstream side by creating a likelihood of failure on the downstream side. Three cases are discussed in this paper regarding the undrained shear strength of the clay core. The values of undrained shear strength were utilized as 20,25 and $30 \mathrm{kN} / \mathrm{m}^{2}$. In every case, the drawdown is shown at different increasing rates of $0.1,0.125,0.25,0.5$ and finally $1 \mathrm{~m} /$ day. The drawdown rates of $0.1 \mathrm{~m} /$ day and $1 \mathrm{~m} /$ day are respectively called as slow drawdown and rapid drawdown of the embankment dam.

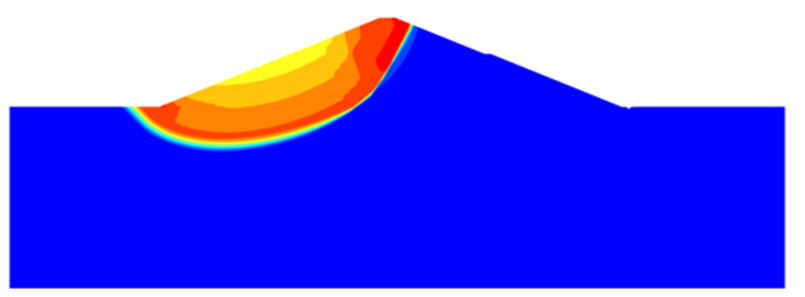

Fig. 5. Failure zone of the dam after the end of construction

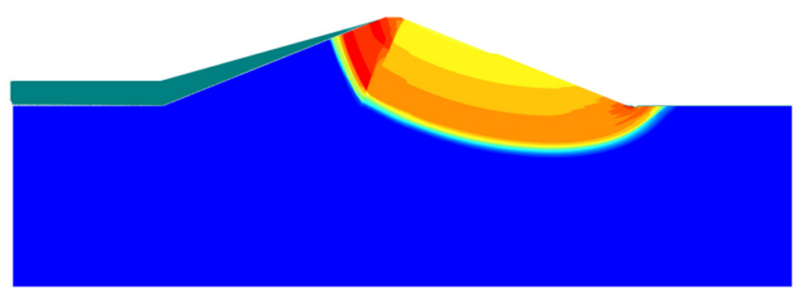

Fig. 6. Failure zone of the dam after the filling of the reservoir

\section{B. Dam Stability during Drawdown when the Undrained Strength of Clay is $20 \mathrm{kN} / \mathrm{m}^{2}$}

Figure 7 shows the safety factor of the embankment dam versus time at different rates of drawdown varying from $0.1 \mathrm{~m} /$ day to $1 \mathrm{~m} /$ day. It can be observed that for rapid drawdown of $1 \mathrm{~m} /$ day, the dam has shown enough stability for up to 15 days ( $15 \mathrm{~m}$ lowering of the reservoir depth) at which the factor of safety was 1.2. When the rapid drawdown of the dam was allowed beyond the 15 days, the dam showed instability in terms of safety factor, which reduced to 0.92 at 35 days (35m lowering of the reservoir). When the reservoir lowered beyond $35 \mathrm{~m}$ depth, the computed results showed complete collapse of the soil, because of the quick lowering of the reservoir, which resulted in imbalance of the support provided by the water to the upstream face. When the rate of drawdown was $0.5 \mathrm{~m} /$ day, the dam showed stability for 30 days (15m lowering of the reservoir), with a factor of safety of 1.2. The dam became instable when the reservoir was lowered continuously beyond 30 days. Figure 7 shows the limiting value of factor of safety of 1.2 as a straight line. The curves of safety factor are plotted for different rates of lowering of the reservoir. Above the limiting value of 1.2 , they are considered satisfactory. If the dam is lowered up to $20 \mathrm{~m}$ at a rate of $0.1 \mathrm{~m} /$ day for 200 days, the dam would be safe with a factor of safety of 1.2 .

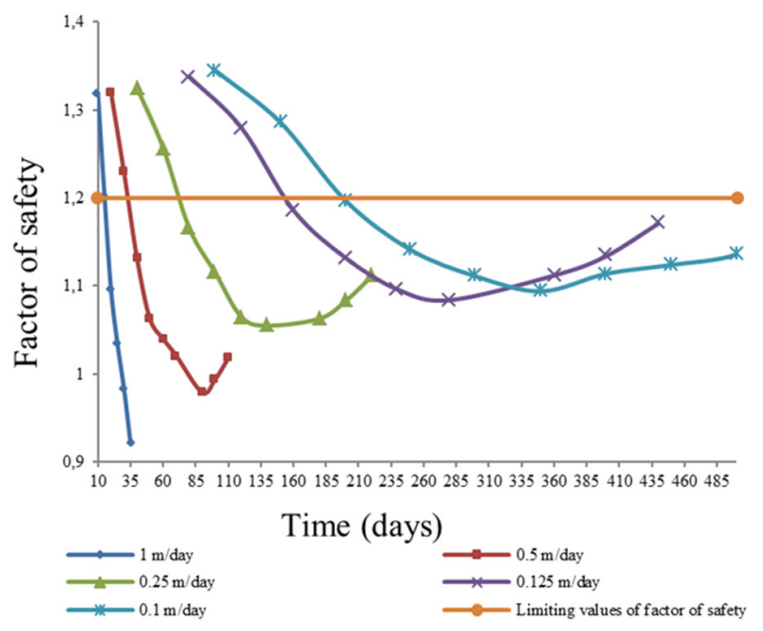

Fig. 7. Safety factor vs time at different rates of lowering of the reservoir, when the undrained shear strength of clay is $20 \mathrm{kN} / \mathrm{m}^{2}$

The failure zones for rapid drawdown at a rate of $1 \mathrm{~m} /$ day (10m depth of lowering of the reservoir) and slow drawdown at a rate of $0.1 \mathrm{~m} /$ day $(20 \mathrm{~m}$ depth of lowering of the reservoir) are shown in Figures 8 and 9. For the rapid drawdown situation, the failure was initiated in clay core and then was extended to the downstream side which is less permeable than the upstream side. For slow drawdown, the failure zone was initiated in the clay core and then was extended to the upstream side of the dam.

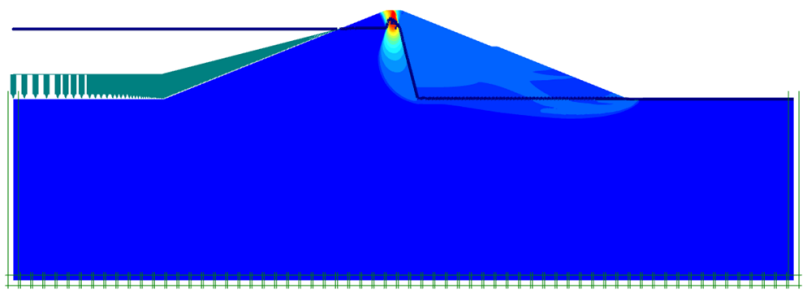

Fig. 8. Failure zone of the dam when the reservoir was lowered at a rate of $1 \mathrm{~m} /$ day for a depth of $10 \mathrm{~m}(\mathrm{Su}=20)$

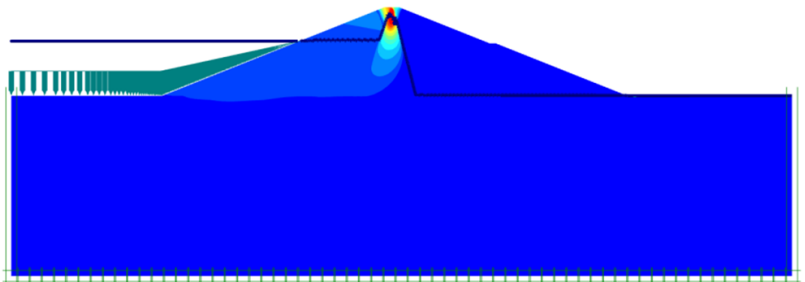

Fig. 9. Failure zone of the dam when the reservoir was lowered at a rate of $0.1 \mathrm{~m} /$ day for a depth of $20 \mathrm{~m}(S u=20)$ 


\section{Dam Stability during Drawdown when the Undrained Strength of Clay is $25 \mathrm{kN} / \mathrm{m}^{2}$}

The safety factor values versus time for different rates of lowering of the reservoir of the dam are shown in Figure 10. It can be observed that when the dam is lowered at the quick drawdown rate, the dam showed stability for up to 20 days (20m lowering of the reservoir) having a factor of safety of 1.2. When the rate of drawdown was $0.5 \mathrm{~m} /$ day, the dam showed stability for up to 40 days with a factor of safety of 1.2. For the slow rate of lowering of the reservoir, the dam showed stability for 550 days ( $55 \mathrm{~m}$ lowering of the reservoir).

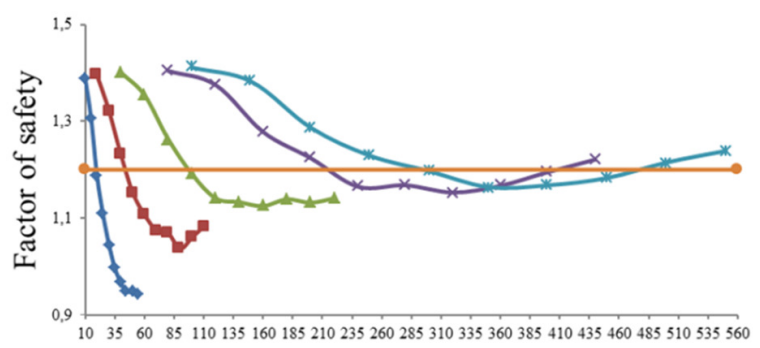

Time (days)
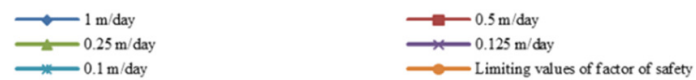

Fig. 10. Safety factor vs time at different rates of lowering of the reservoir, when the undrained shear strength of clay is $25 \mathrm{kN} / \mathrm{m}^{2}$

The failure zones for rapid and slow drawdown are respectively shown in Figures 11 and 12. For both situations, the failure was initiated in the clay core and was then extended to upstream side of the dam.

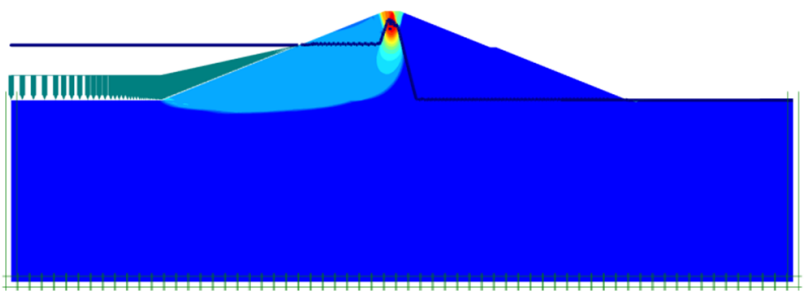

Fig. 11. Failure zone of the dam when the reservoir was lowered at a rate of $1 \mathrm{~m} /$ day for a depth of $20 \mathrm{~m}(S u=25)$

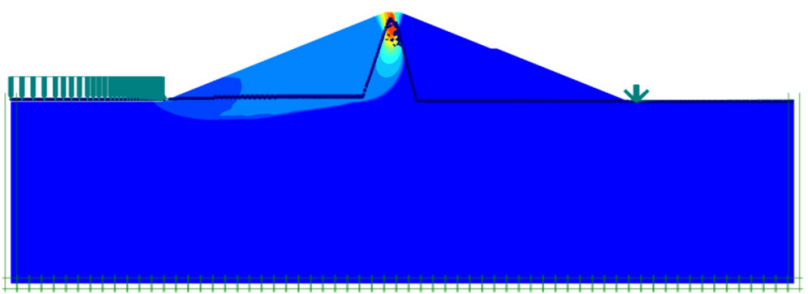

Fig. 12. Failure zone of the dam when the reservoir was lowered at a rate of $0.1 \mathrm{~m} /$ day for a depth of $55 \mathrm{~m}(S u=25)$

\section{Dam Stability during Drawdown when the Undrained Strength of Clay is $30 \mathrm{kN} / \mathrm{m}^{2}$}

Figure 13 illustrates that the dam is safe if its reservoir is lowered up to a depth of $55 \mathrm{~m}$ even at a rate of $0.25 \mathrm{~m} /$ day in
220 days. If the lowering of the reservoir is performed quickly at a rate of $1 \mathrm{~m} /$ day, the dam is stable up to a depth of $23 \mathrm{~m}$ only. It is also interesting to note that for all rates of lowering of the reservoir, the factor of safety initially decreased and then gradually increased even when the lowering was continued beyond the depth of $35 \mathrm{~m}$, because the clay core and upstream material (sandy gravel) are wider at the base than at the top surface. Due to the bigger width of the clay core and upstream sandy gravel at the deeper layers of the dam, the soil became more hardened, therefore the safety factor was increased. In general, a decrease in drawdown rate showed an increase in the safety factor of the dam. This indicates that the stability of the dam improved when the drawdown rate was relatively reduced.

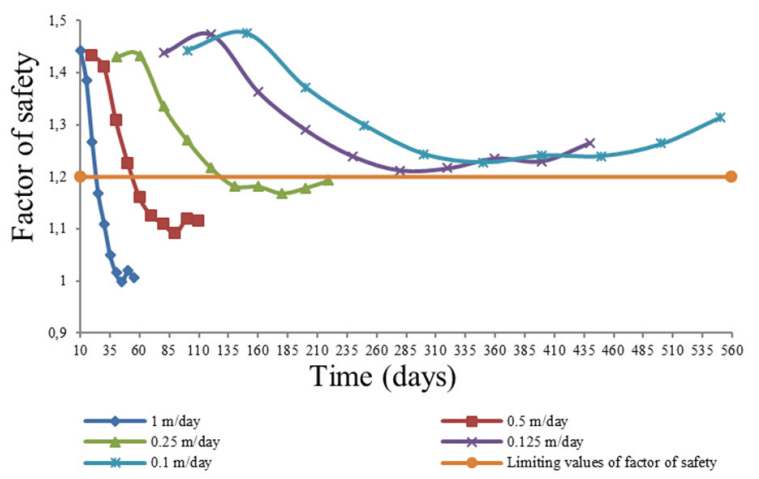

Fig. 13. Safety factor vs time at different rates of lowering of the reservoir, when the undrained shear strength of clay is $30 \mathrm{kN} / \mathrm{m}^{2}$

The failure zones for rapid and slow drawdown are shown respectively in Figures 14 and 15. For both cases the failure was initiated in the clay core and was then extended to the upstream side of the dam.

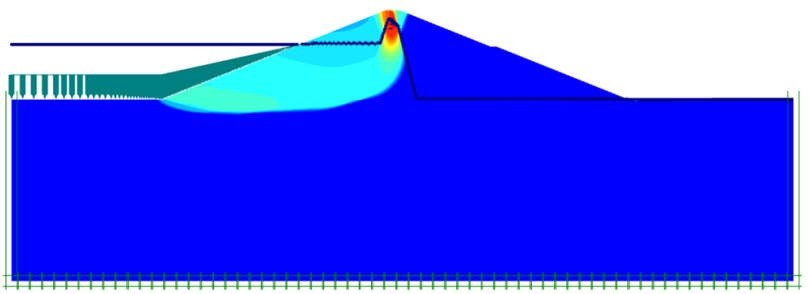

Fig. 14. Failure zone of the dam when the reservoir was lowered at a rate of $1 \mathrm{~m} /$ day for a depth of $20 \mathrm{~m}(S u=30)$

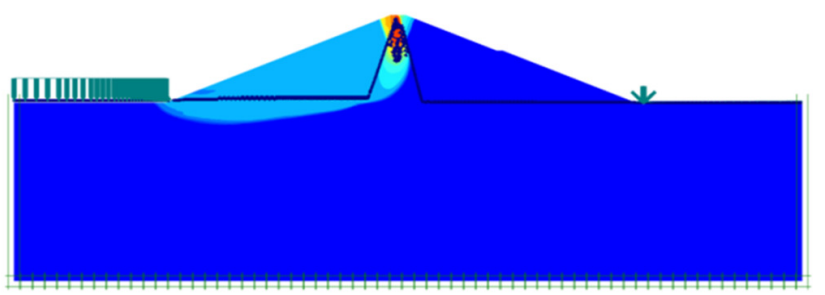

Fig. 15. Failure zone of the dam when the reservoir was lowered at a rate of $0.1 \mathrm{~m} /$ day for a depth of $55 \mathrm{~m}(S u=30)$

\section{E. Pore Pressure during Rapid Drawdown}

In addition to stability during rapid drawdown and slow drawdown of the dam, it is also necessary to observe how the 
excess pore pressure and total pore pressure have developed and dissipated with respect to time. A detailed summary of the development and dissipation of pore pressure is presented in Table II. It can be observed that the total pore pressure has been reduced as the reservoir level lowered from 0 to $55 \mathrm{~m}$. Excess pore pressure has been developed more quickly during rapid drawdown and at a relatively slower rate during slow drawdown.

TABLE II. DEVELOPMENT AND DISSIPATION OF EXCESSIVE AND TOTAL PORE PRESSURE DURING DRAWDOWN

\begin{tabular}{|c|c|c|c|c|}
\hline $\begin{array}{c}\text { Undrained shear } \\
\text { strength } \boldsymbol{S u} \\
\left(\mathbf{k N} / \mathbf{m}^{\mathbf{2}} \mathbf{)}\right.\end{array}$ & $\begin{array}{c}\text { Drawdown } \\
\text { rate } \\
\text { (m/day) }\end{array}$ & $\begin{array}{c}\text { Drawdown } \\
\text { depth }(\mathbf{m})\end{array}$ & $\begin{array}{c}\text { Compressive } \\
\text { pore } \\
\text { pressure }\end{array}$ & $\begin{array}{c}\text { Compressive } \\
\text { excess pore } \\
\text { pressure }\end{array}$ \\
\hline & $\begin{array}{c}\text { After } \\
\text { reservoir } \\
\text { filling }\end{array}$ & 0 & 1700 & 120 \\
\hline 20 & 1 & 10 & 1600 & 360 \\
\hline 20 & 0.1 & 20 & 1600 & 280 \\
\hline 25 & 1 & 20 & 1600 & 335 \\
\hline 25 & 0.1 & 55 & 1400 & 320 \\
\hline 30 & 1 & 20 & 1600 & 300 \\
\hline 30 & 0.1 & 55 & 1400 & 280 \\
\hline
\end{tabular}

\section{CONCLUSION}

In this paper, the results of numerical modeling of safe lowering rate of the reservoir are presented. It was observed that the safe lowering rate of the reservoir depends mainly on the magnitude of the undrained shear strength of the clay core. Adoption of a value of $25 \mathrm{kN} / \mathrm{m}^{2}$ is suggested for the undrained shear strength of the clay. The computed results indicate that the reservoir of the dam could be lowered safely up to $20 \mathrm{~m}$ and $55 \mathrm{~m}$, if the rates of drawdown are respectively $1 \mathrm{~m} /$ day (rapid drawdown) and $0.1 \mathrm{~m} /$ day (slow drawdown).

\section{REFERENCES}

[1] A. H. Bhutto, S. Zardari, G. S. Bhurgri, M. A. Zardari, R. Bhanbhro, B. A. Memon, M. M. Babar, "Mohr-Coulomb and hardening soil model comparison of the settlement of an embankment dam", Engineering, Technology \& Applied Science Research Vol. 9, No. 5, pp. 4654-4658, 2019

[2] A. H. Bhutto, S. Zardari, G. S. Bhurgri, M. A. Zardari, R. Bhanbhro, B A. Memon, M. M. Babar, "Post construction and long term settlement of an embankment dam computed with two constitutive models", Engineering, Technology \& Applied Science Research Vol. 9, No. 5, pp. 4750-4754, 2019

[3] A. H. Bhutto, S. Zardari, G. S. Bhurgri, M. A. Zardari, R. Bhanbhro, B. A. Memon, M. M. Babar, "Parametric analysis of stability of an embankment dam", Engineering, Technology \& Applied Science Research, Vol. 9, No. 6, pp. 5016-5020, 2019

[4] S. S. Athani, C. H. Solanki, G. R. Dodagoudar, "Seepage and stability analyses of earth dam using finite element method", Aquatic Procedia,Vol. 4, pp. 876-883, 2015

[5] D. R. Vandenberge, "Total stress rapid drawdown analysis of the Pilarcitos dam failure using the finite element method", Frontiers of Structural and Civil Engineering, Vol. 8, No. 2, pp. 115-123, 2014

[6] M. M. Berilgen, "Investigation of stability of slopes under drawdown conditions", Computers and Geotechnics, Vol. 34, No. 2, pp. 81-91, 2007

[7] H. Hasani, J. Mamizadeh, H. Karimi, "Stability of slope and seepage analysis in earth fills dams using numerical models. (case study: Ilam dam-Iran)", World Applied Sciences Journal, Vol. 21, No. 9, pp. 13981402,2013
[8] M. Y. Fattah, H. A. Omran, M. A. Hassan, "Behavior of an earth dam during rapid drawdown of water in reservoir: Case study", International Journal of Advanced Research, Vol. 3, No. 10, pp. 110-122, 2015

[9] S. A. Khattab, "Stability analysis of Mosul dam under saturated and unsaturated soil conditions", Al Rafdain Engineering Journal, Vol. 18, No. 1, pp. 13-27, 2010

[10] Y. Gao, D. Zhu, F. Zhang, G. H. Lei, H. Qin, "Stability analysis of three-dimensional slopes under water drawdown conditions", Canadian Geotechnical Journal, Vol. 51, No. 11, pp. 1355-1364, 2014

[11] N. M. Pinyol, E. E. Alonso, S. Olivella, "Rapid drawdown in slopes and embankments", Water Resources Research, Vol. 44, No. 5, 2008

[12] R. B. J. Brinkgreve, S. Kumarswamy, W. M. Swolfs, Plaxis reference manual, PLAXIS bv, 2017

[13] WAPDA, Project planning report of Nai Gaj dam, Water And Power Development Authority of Pakistan, 2006

[14] J. Schleiss, R. M Boes, Dams and reservoirs under changing challenges, CRC Press, 2011

[15] M. Carter, S. P. Bentley, Soil properties and their correlations, John Wiley \& Sons, 2016

[16] F. Cobb, Structural engineer's pocket book: British standards edition, Elsevier, 2008

[17] R. F. Craig, Soil mechanics, Springer, 2013

[18] R. A. Rajapakse, Geotechnical engineering calculations and rules of thumb, Butterworth-Heinemann, 2015

[19] G. E. Barnes, Soil mechanics: Principles and practice, Palgrave MacMillan, 2011

[20] J. L. Justo, J. Saura, "Three-dimensional analysis of Infiernillo dam during construction and filling of the reservoir", International Journal for Numerical and Analytical Methods in Geomechanics, Vol. 7, No. 2, pp. 225-243, 1983

[21] B. G. Look, Handbook of geotechnical investigation and design tables, CRC Press, 2014

[22] M. N. Sara, Site assessment and remediation handbook, CRC Press, 2003

[23] P. J. Burgess, D. Sarabia, J. Small, H. G. Poulos, J. Sinha, "Settlement behaviour of a major dam", ANCOLD 2006 Conference: Dams: The Challenges of the 21st century, Manly, Australia, November 19-22, 2006

[24] L. Ormann, M. A. Zardari, H. Mattsson, A. Bjelkevik, S. Knutsson, "Numerical analysis of strengthening by rock fill embankments on an upstream tailings dam", Canadian Geotechnical Journal, Vol. 50, No. 4, pp. 391-399, 2013

[25] D. U. Deere, R. P. Miller, Engineering classification and index properties for intact rock, Air Force Systems Command, 1966

[26] N. A Trenter, Earthworks: A guide, Thomas Telford Limited, 2001 